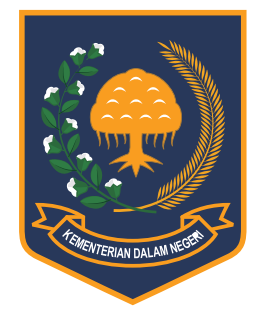

Jurnal Bina Praja 9 (1) (2017): 115-126

Jurnal Bina Praja

e-ISSN: 2503-3360 | p-ISSN: 2085-4323

Accreditation Number

735/AU2/P2MI-LIPI/04/2016

http://jurnal.kemendagri.go.id/index.php/jbp/index

\title{
The STREngthening OF Region CoMpetitivenesS BY IMPLEMENTING CiTY BRANDING IN YOGYAKARTA
}

\author{
Mercy Pasande ${ }^{1}$, Adi Suhendra ${ }^{2, *}$ \\ ${ }^{1,2}$ Research and Development Agency \\ Ministry of Home Affairs \\ Jl. Kramat Raya No. 132, Central Jakarta
}

Received: 16 February 2017; Accepted: 6 May 2017; Published online: 31 May 2017

DOI: $10.21787 / j b p .09 .2017 .115-126$

\begin{abstract}
This study is about City Branding. This research is motivated by the potential of City Branding creation as a way to improve regional competitiveness. The purpose of this study is to describe the various efforts made by the local government of DIY to improve the competitiveness of the region with City Branding. This research uses the qualitative method. Data collection method is done by triangulation technique of data source. While data processing researcher does data reduction. The results obtained in this study are First, City Branding DIY has been running well. Rebranding DIY is likely to increase the competitiveness of regions, including local revenue. This is evidenced by the increase in investment achieved by the Government of Yogyakarta. It's just that City Branding is still focused on tourism, but it can be used for other sectors. Second, the DIY rebranding (2014) provides many improvements, especially in terms of concept, logo, and tagline. In addition, the Yogyakarta provincial government has established city branding councils, city branding strategy roadmap and governor regulation of city branding in DIY. It's just that there has been no evaluation since the rebranding was done by the provincial government of DIY, how this rebranding can be implemented by the local government and city branding council and there is no extent to which the strategy in the roadmap implemented.
\end{abstract}

Keywords: City Branding, Local Authorities, Regional Innovation

\section{INTRODUCTION}

The Annual Global Competitiveness Report World Economic Forum (WEF) shows Indonesia's competitiveness ranked 44th in 2011, down two points to 46th in 2012., decrease by four points to 50th in 2013. Then In 2014, Indonesia rose to 38th and again rose to 34th in 2015, however, in 2016 Indonesia fell back to 37th and 144th countries in the world (Klaus Schwab, 2016). This indicates that during the last 5 (five) years Indonesia's competitiveness may be said to be stagnant.

However, when we look at the global economic growth, Indonesian economic growth is quite good. In 2013 Indonesia economic growth was 5.8 percent, 5.1 percent in 2014 and 4.79 percent in 2015 (OECD, 2015). Despite suffering from the impact of three times global crisis, Indonesia is still able to survive and be able to compete in global trade (Dimasyq Ozal, 2012).
In that context, certainly, national competitiveness cannot be separated from the efforts of local governments to strengthen regional competitiveness. National competitiveness is the capacity of the nation to face the challenges of international market competition and keep or increase its real income. Meanwhile, the regional competitiveness is more on the ability to attract foreign investment and its productive role.

Medic et al. Research (2010) explains that one way to strengthened regional competitiveness is by City Branding. Caldwell \& Freire (2004) in their study also explained that concept of City Branding is a symbol that became the identity of a city. City Branding can also be interpreted as a strategic effort of a city to create a strong positioning regionally and globally. With the City Branding, a city can form a more useful identity to market all of its activities, infrastructures, and cultures.

Several types of research have been done on

\footnotetext{
* Corresponding Author

Phone : +62 82244468840

Email : adisuhendra.pm@gmail.com
} 
City Branding. Pessoa, (2013) for example states that by adopting City Branding regional heads can attract many tourists, which is a catalyst for improving regional competitiveness. While the study of Akgun et.al (2016) also explains that City Branding is seen as a strategic instrument that promotes the competitiveness of a city, it is a broad platform to market the history, the quality of the place, natural resources, culture and social opportunities of the city and strengthening its competitiveness.

Other scientists are more concern on urban planning. According to Kavaratzis \& Ashworth, (2005) City Branding is a strategy of a city or region to create a strong positioning in the mind of their target market, just like the positioning of a product or service. A city can be widely known either regionally or globally. With so many advantages, many regions are trying to improve its competitiveness by branding its city. Even though Kavaratzis \& Ashworth only see branding in terms of communication or marketing of the city.

Some Indonesian researchers also conduct studies on City Branding. Studies conducted by Indonesian researcher also emphasize on the point of view of city identity, location in urban development. Research conducted by (Maylanny and Fauzan (2013) states that City Branding in a city must have a clear identity, as in Bandung, the branding is done by using Bandung Tour on Bus (Bandros).

In line with Maylanny and Fauzan, a study conducted by Risanto \& Yulianti (2016) in Pasuruan mentioned that natural resource such as a forest can be used as city identity. City Branding may be done by developing a green tourism area by looking at the potential of existing natural resources.

Unlike the two previous local researchers, Lily and Lukito (2014) who conducted research in Batam City, indicates that factors affecting the brand of Batam City as a place of residence for the business group (brand attitude to doing business in the city) are a business opportunity, transportation, and networking.

Nevertheless, the above research only examines from two points of view, the identity of the city and the city planning. In contrast to the above research, this study looks from a comprehensive point of view. Not only from the point of view of urban identity and urban planning, this study looks at how the regulation, the city's competitiveness potential, the social community, and the creative actors in City Branding development.

Based on a theoretical framework initiated by Prophet (2006), there are at least eight main points in branding a city, which are: setting the purpose, understanding the target audience, identifying current brand image, organizing brand aspiration identities, developing positioning steps, creating propositional values, executing steps identified in branding strategies, and measuring the result. The theoretical framework provides an overview and appraisal of a brand in a city.

This study is a case study conducted in Special Region Yogyakarta in strengthening the regional competitiveness with city branding. This research also reveals several supporting and inhibiting factors in branding a region. For the rest of the article, we will use the term "DIY" a popular name of the city, or Yogyakarta, another popular name of the city). Based on supporting data, so far DIY has issued several regulations and documents about city branding. In addition, in an effort to brand the city, DIY received awards from Tempo Media Group and Frontier Consulting Group as Best City and Best City- Tourism Category in the event Indonesia Attractiveness Award 2016. Indonesia Attractiveness Index 2016 measure based on four approaches or dimensions which are: of investment, infrastructure, tourism and public services (Lea, 2016).

This research is also considered important and relevant because it sees the contemporary context in Indonesia. Especially with the existence of Article 386-390 in regional innovation in the Law Number 23 of 2014 on Regional Government and its derivative rules, this study becoming more important to be performed to provide input to policy formulation by the Ministry of Home Affairs on regional competitiveness. In accordance with the general explanation of the Act, the granting of the broadest autonomy to the Region is directed to accelerate the improvement of community welfare, through the improvement of services, empowerment, and community participation. In addition, through the broad autonomy, the region is expected to improve its competitiveness (Law Number 23 of 2014 regarding Regional Government, Government of the Republic of Indonesia, 2014).

The law provides a wider opportunity for the local governments to manage its territory, brand a city, sell the uniqueness of the city, and attract tourists to visit and even invest. In addition, the inclusion of urban issues as a national priority thematic issue makes this topic highly relevant to be studied in accordance with the topics and issues of competitive assessment.

Indeed, City Branding attempts to provide a different identity for a city, so it can be distinguished between one city to another. A strong brand means the brand can be distinguished from competitors so that it will result in increased investment, business, tourism, visitors, and residents. A strong brand will first increase the awareness of the existence of the place.

Second, the brand will make the city's potential customers consider the quality of a city better than 


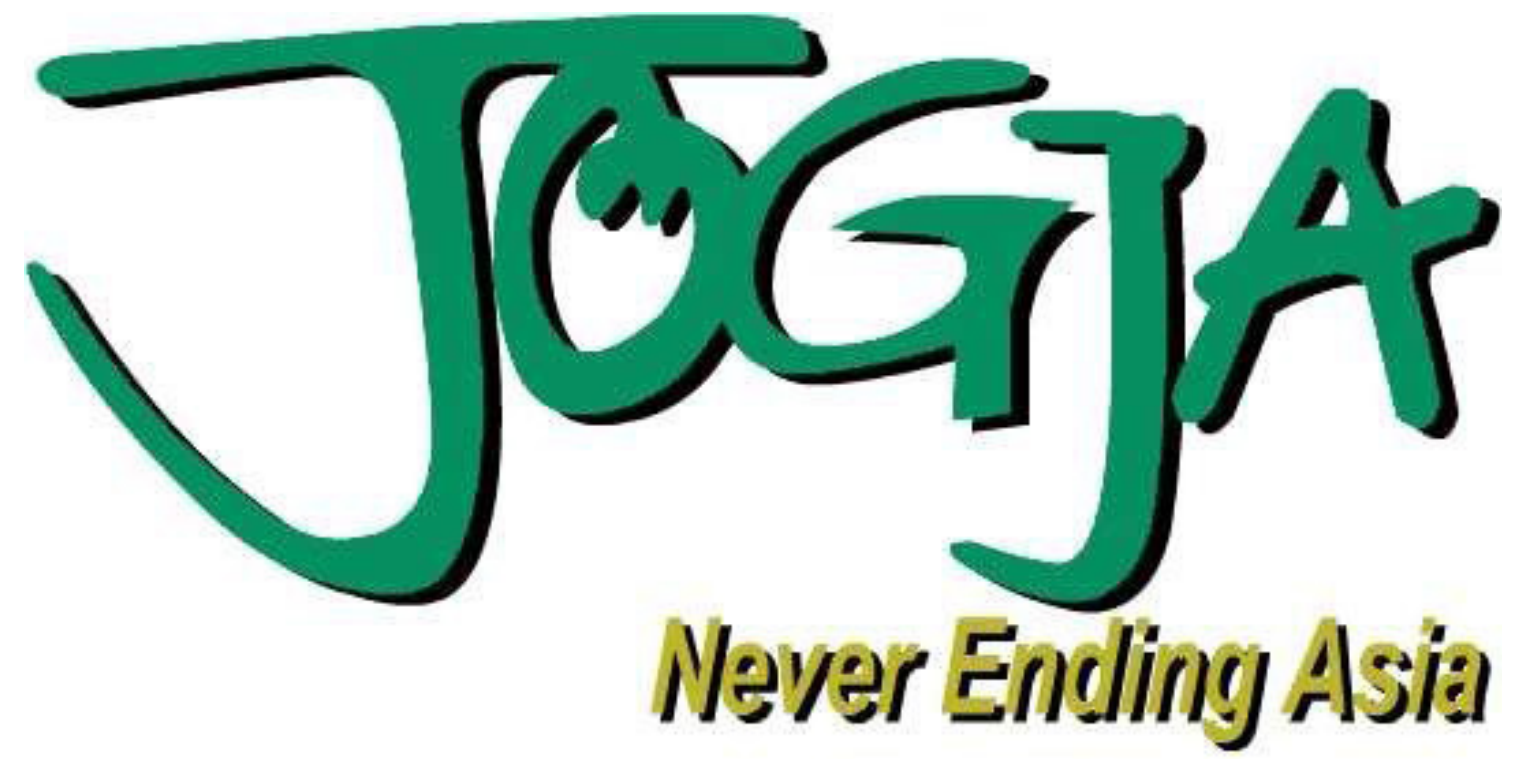

Figure 1. Logo and Tagline City Branding Year 2001 Source: Bappeda DIY

any other cities. Finally, a good brand may be used to control how the city is run and City Branding as a regional innovation will enhance a city's competitiveness. Nevertheless, the main challenge is actually forming an 'umbrella' image of the city that is coherent in for various areas of activity, with a variety of target user, while at the same time also forming specific urban image communications.

\section{MeThOD}

This study was conducted in DIY using a qualitative approach. The Qualitative Approach is an approach that gives researchers the opportunity to describe the subject sharply and gain depth of information, as well as a wealth of interpretation (Somantri, 2005).

The data collection method is done by triangulation technique of data source. According to Denzin (2012) triangulation of data sources is exploring the true information through various methods and sources of data acquisition. For example, in addition to interviews and observations, written documents, archives, historical documents, official records, personal notes or writings, and pictures or photographs could be used as a data source. Each it will produce different evidence or data, which will then provide different insights about the phenomenon being studied.

The interview process was conducted on several sources residing in DIY which is divided into two groups. The first group is from the local government while the second group is from the non-local government.

From Local Government group, one person from DIY Privileges Assistant Unit, Cultural section, two persons from DIY Tourism and Culture Office, two persons from Regional Planning and Development Board, and two persons from Economic Development of Local Revenue and Cooperation Unit of Yogyakarta City.

From non-regional government are one Community Leader, the owner of Dagadu Jogja brand, and the surrounding community. In addition, data sources are also obtained from newspapers and electronic medias regarding DIY city branding.

Data reduction was done by researchers throughout this research process. As explained by (Berg, 2001) data reduction is intended to draw attention to the focus of research needs, simplify, and transform raw data into a more manageable form.

\section{RESULTS AND DISCUSSIONS}

\section{A. The Birth of City Branding in DIY}

At the international level, city marketing programs conducted through place branding have been widely implemented. Some cities in the world have implemented City Branding strategy, ranging from cities in the Europe, Australia, to Asia. Just like the Dutch city "I Amsterdam" is the motto of the city re-branding of Amsterdam, Singapore with Uniquely Singapore and Brisbane with Australia's New World City. It is undeniable that the success of a region to develop its potential depends on the integrated marketing activities it does.

Observing City Branding in Indonesia, we cannot overlook DIY. Branding DIY first appeared in 2001. According to Head of Culture Unit Extraordinary Assistant at that time the slogan 
"Never Ending Asia" is proposed as the tagline for Jogja. DIY Provincial Governor, Sri Sultan Hamengku Buwono $\mathrm{X}$ suggested the idea create branding for the city.

Local Government of DIY assisted by Markplus Inc. finally gave birth of the brand "Jogja Never Ending Asia". At that time, Yogyakarta is expected to become a pioneer or leader in the Asian region in the realm of trade, tourism and industry within the next five years. The meaning of the word Jogja Never Ending Asia means Jogja became a famous region or city in Asia, by using the concept of never ending tourism.

The concept of tourism in being proposed by the DIY government is not without reason. The Head of Tourism Services Section, Tourism Department of DIY explained tourism is chosen as a branding concept is backed by a strong cultural factor. DIY was once the center of the Islamic Mataram Empire, the Yogyakarta Sultanate, and the Pakualaman. DIY is also known as the city of culture, it is associated with high-value cultural heritage during the reign of the kingdoms, and which until now remain sustainable. The city is related to the many centers of art and culture. DIY as a tourism city illustrates the potential of this province for tourism. DIY is the second largest tourist destination after Bali. Various types of objects developed in this region, such as natural objects, historical tourism, cultural tourism, educational tourism, and religious tourism.

In more detail, the tourism objects are classified into three categories, (1) Natural Tourism Objects, which are beaches, mountains, and caves, (2) Historical Tourism Objects, in the form of historical relics of the (Javanese) kingdom, cemetery, and so forth. For example, Kraton Yogyakarta, Tamansari, Imogiri Cemetery (tomb of Mataram kings); Prambanan Temple, Kalasan Temple, Petilasan Ratu Boko, and others, (3) Cultural Tourism Object, which is a public cultural object that is still well preserved, such as Ramayana Ballet, Wayang Kulit, Wayang Golek, Sekaten, Grebeg Maulud, Grebeg Syawal, Grebeg Besar and Labuan. Yogyakarta landmark is the Monument of Yogyakarta which is a monument or tower that is often used as a symbol of the city of Yogyakarta.

According to the official website of DIY (Provincial DIY, 2011), there are 3 (three) that fundamental reason for DIY to create the brand "Jogja Never Ending Asia." First, the economic crisis that has continued into a multidimensional crisis since a few years ago has had a serious impact on Political, economic and social conditions, causing investors, traders and tourists to be worried about visiting, under conditions of such uncertainty. BPS data illustrates that one of the serious impacts of the financial crisis on the Indonesian economy in the era of 98 was to increase the unemployment number. BPS data in 1998 shows that during the 1997-1998 periods, the termination of employment reach to 4.4 million workers, although the economy recovered and economic growth increased, the unemployment condition in Indonesia has not improved (Adiningsih, 2008).

With the formulation of DIY branding, at least there are some efforts made by Provincial Government to show a relatively safe and peaceful area with the spirit of harmony, mutual respect, and democracy. These conducive and favorable conditions must always be maintained so that the good image of Yogyakarta will continue to be embedded in the minds of investors, business people, and tourists, both domestic and foreign.

Secondly, the globalization era, reflected in the term 4i (industry, investment, information, and individualism) has spurred competition among nations, between regions to seize world markets. A study conducted by The Indonesian Institute, before the outbreak of the monetary crisis, Indonesia managed to maintain its balance of payments surplus, of an average per year of 2.574 billion US dollars during the period 1990-1996. While the third factor in the first year of the crisis, Indonesia must face a balance of payments deficit of 2.459 US dollars. A large deficit in the balance of payments is due to the huge outflows of private capital. In such competitive conditions, to win. DIY needs to seriously establish clear, positioning, strong differentiation and build a unique brand image.

Third, DIY has realized that marketing places will encourage the growth of trade, tourism, and investment or TTI (trade, tourism, investment) to encourage economic growth. Yogyakarta also sees that brand image building strategy is very much needed because the brand will become a value indicator that will be supported by all stakeholders in DIY.

However, after 14 years, the Local Government of DIY feels the need to Re-brand Jogja. The idea of logo changes as well as rebranding Jogja actually started from the Governor of Yogyakarta, Sri Sultan Hamengkubuwono X. The number 1 person in DIY considered that the old logo that has survived for 14 years, is now no longer relevant. In addition, the tagline "Jogja Never Ending Asia" is also considered necessary to be changed (http://www. jogjaistimewa.co/rebranding-jogja-tak-sekadarganti-logo/ accessible 24 May 2016).

Minutes of the Discussion of "Identity of Jogja in the Perspective of Citizens and Heritage Buildings" organized by The Tusti Jogja Community on Thursday, July 17, 2014, in Yogyakarta.

The moderated discussion presented three resource persons, namely $M$. Natsier (Kanthil Kotagede Foundation), Priya Pratikno (Department of Architecture UKDW), and Edy SR (Brandpreneur) 


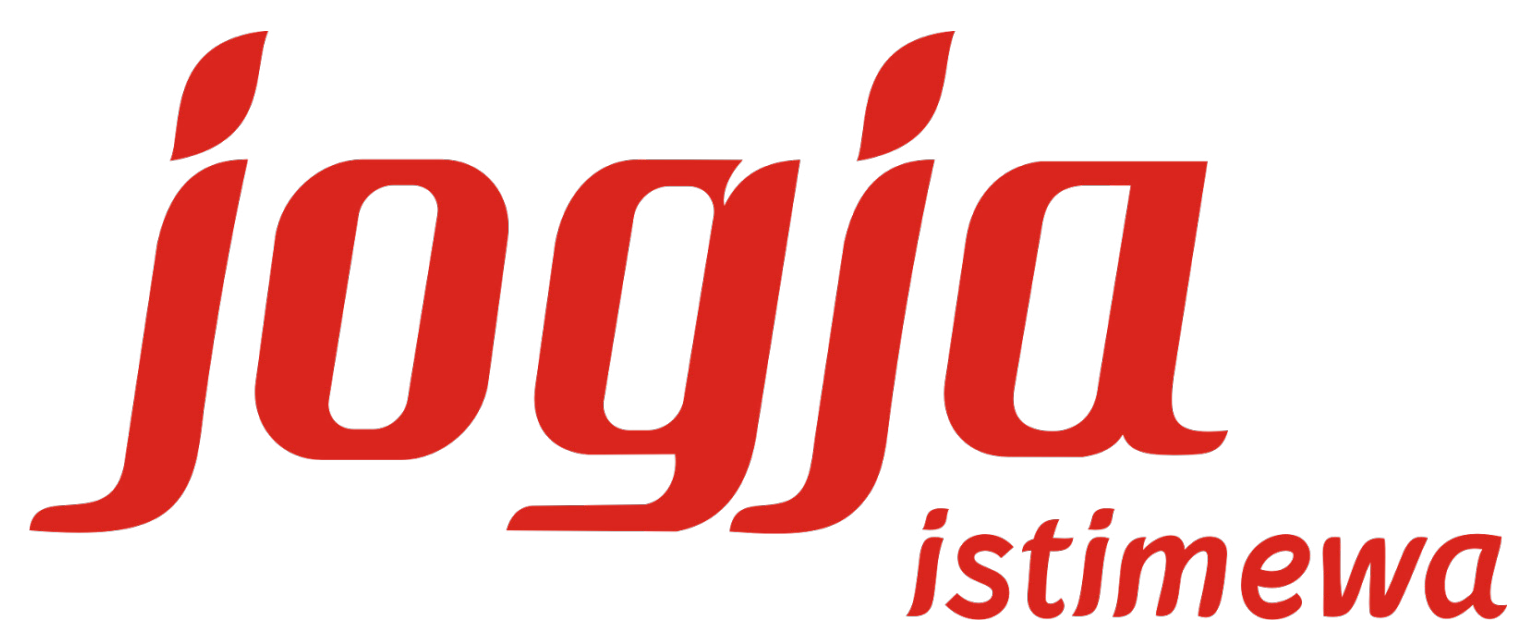

Figure 2. Rebranding Logo Jogja Istimewa Year 2014 Source: Bappeda DIY

data from Bappeda DIY explained that the rebranding of Jogja is expected to encourage the spirit of a new civilization which will produce the ideal human being.

Based on the thought of Sri Sultan HB X, Hermawan Kartajaya proposed "Jogja The Spirit of Indonesia” as a rebrand for Yogyakarta. However, Edy SR considers that the concept of DIY rebrand at that time was interpreted as un-original (imitating the branding of Surakarta city, "Solo, The Spirit of Java"). On the other hand, the emergence of new brands overlooks the fact that Yogyakarta actually already has a good branding strategy in every region of the district / city in Yogyakarta. We remember the slogan "Yogyakarta Berhati Nyaman", "Sleman Sembada", "Bantul Projo Tamansari", "Gunungkidul Handayani", and "Kulon Progo Binangun". The more inward-oriented tagline is then less popular with the new, more outward-oriented tagline, as a branding strategy.

Since early 2014, Yogyakarta has been preparing to rebrand its city by replacing the logo and tagline of the city. Sultan Hamengkubuwono has selected Hermawan Kertajaya team, the founder of MarkPlus Inc., to create a new logo based on its direction. This is mainly because of the previous logo, Jogja Never Ending Asia, also made by Hermawan team, and it successfully brings up the name of Yogyakarta both in Indonesia and international arena.

Coinciding with the grand event "Great Pisowanan" on March7, 2014 DIY introduces new tagline logo for DIY, "Jogja Istimewa” (Jogja extraordinaire ). Pisowanan is a tradition in the kingdoms of Java, where subordinates of the king/ sultan came to the palace to report the progress of their area. Pisowanan arguably is a form of accountability of local leaders to the king. After listening to reports of subordinates, king /sultan will usually give advice, reprimand, or command (command) for each district leaders.

The difference between the old branding (2001) and the new branding (2014) is first, lies in the concept. Sri Sultan HB X stated that the Law of Privilege of Yogyakarta became the main driving factor this re-branding idea. The two things proposed by the Sultan for the new branding are the concept of Jogja Renaissance and Sabdatama Raja (literally means the King's command) spirit.

According to one of the heads of the field in Bappeda, Yogyakarta new logo and slogan is made based on the mandate of Sultan Hamengku Buwono $\mathrm{X}$ as the King of Yogyakarta Sultanate delivered on May 10, 2012. Another reference is the vision and mission of the Sultan as Governor of DIY which is often called “Jogja Renaissance”. Jogja's Renaissance illustrates Jogja's steps towards a new civilization in education, tourism, technology, food, energy, economy, health, citizen protection, spatial plan and environmental. Both of these are expected to be translations of DIY vision in welcoming the extraordinary nature of Yogyakarta.

The logo and DIY tagline in the second branding program can be seen in Figure 2.

Second, Jogja new brand is created with deep meaning.

Further explained by the Head of Culture Division Extraordinary DIY Assistant that the new logo inscribed "jogja" written with lowercase as a whole, using red brick with white background. Written in lowercase, symbolizes egalitarianism, equality, and brotherhood. Red brick color as the symbol of the palace depicting the courage to endeavor in the new era, armed with the past culture enriched in the unique local wisdom.

Third, to support the implementation of the DIY rebranding, the Provincial Government issued the Governor's Regulation to legitimize it. The regulation is set forth in Governor Regulation 
Table 1.

Identification and Mapping of City Branding Policy in DIY

\begin{tabular}{cccc} 
Id & Number & Year & Regarding \\
\hline Law & 3 & 1950 & $\begin{array}{c}\text { Establishment of Special } \\
\text { Region of Jogjakarta }\end{array}$ \\
\hline Law & 32 & 2004 & Regional Government \\
\hline Law & 26 & 2007 & Spatial Plan \\
\hline Law & 13 & 2012 & $\begin{array}{c}\text { The Privileges of Special } \\
\text { Region of Yogyakarta }\end{array}$ \\
\hline $\begin{array}{c}\text { Regional Government } \\
\text { Regulation }\end{array}$ & 1 & 2012 & $\begin{array}{c}\text { Tourism Masterplan } \\
\text { of Special Region of } \\
\text { Yogyakarta Year 2012-2025 }\end{array}$ \\
\hline $\begin{array}{c}\text { Regional Government } \\
\text { Regulation }\end{array}$ & 1 & 2013 & $\begin{array}{l}\text { Authority in the Privileges } \\
\text { matters of Special Region } \\
\text { of Yogyakarta }\end{array}$ \\
\hline $\begin{array}{c}\text { Governor Regulation } \\
\text { Roadmap }\end{array}$ & 10 & 2014 & $\begin{array}{c}\text { Brand/Logo of Special } \\
\text { Region of Yogyakarta }\end{array}$ \\
\hline Document & 2015 & $\begin{array}{l}\text { Strategic Road Map } \\
\text { implementation plan } \\
\text { of Special Region of } \\
\text { Yogyakarta City Brand }\end{array}$ \\
\hline
\end{tabular}

Number 10 of 2014 on the Brand/Logo Daerah Istimewa Yogyakarta.

The regulation was made in reference to Law Number 3 of 1950 on the Establishment of the Special Territory of Jogjakarta, Law Number 32 of 2004 which has been converted into Law 23 of 2014 on Regional Government, Law 26 of 2007 on Spatial Planning and Law Number 13 of 2012 About the Privileges of Special Region of Yogyakarta. Governor Regulation Number 10 of 2014 on Brand/ Logo Daerah Istimewa Yogyakarta. The purpose of the legal products above is to ensure that the City Branding can be well implemented.

DIY Governor's policy in city branding refers to the Law Number 13 of 2012 on Special Privileges of the Special Region of Yogyakarta. When viewed from the policy analysis, this Law describes the points as follows:

1. this Law legitimizing the regional authority to market an area. The consideration of this is that the state recognizes and respects special or privileged regional government based on the law;

2. that the Sultanate of Ngayogyakarta Hadiningrat and the Pakualaman Kadipaten that had its own territory, government and the inhabitants before the birth of the Unitary State of the Republic of Indonesia on 17 August 1945 had a role and had made a great contribution in defending, and maintaining the integrity of the Unitary State of the Republic of Indonesia;

3. that Law Number 3 of 1950 on the Establishment of Special Territory of Jogjakarta as already amended several times, most recently by Law Number 9 of 1955 on Amendment of Law Number 3 jo. Number 19 of 1950 on the Establishment of the Special Region of Yogyakarta has not been regulating fully about the privileges of Yogyakarta Special Region.

To strengthen the image of the city, the local government of Yogyakarta also issued the Special Territory of Yogyakarta Regulation Number 1 of 2013 regarding Authority in privileges matters of the Special Region of Yogyakarta.

The Government of Yogyakarta deemed it is necessary to stipulate a regulation on the authority in privileges matters of the special region of Yogyakarta, based on the provisions of Article 7 paragraph (4) of Law Number 13 of 2012 concerning the special privileges of Yogyakarta.

This regional regulation regulates: (1) the procedures for filling the positions, duties, and authorities of the Governor and Vice Governor; (2) the regional government institution; (3) culture; (4) land; And (5) spatial planning. The purpose of this regional regulation is to oversee and implement Law 13 of 2012 on the special privileges of Yogyakarta. 
Determination of DIY City Branding was performed by the issuance of Regulation of Governor of Special Region of Yogyakarta Number 10 of 2014 About the Brand/Logo of Special Region of Yogyakarta.

This regulation was issued to enliven the spirit of local governance based on vision, mission and create an exclusive image, Jogja reformulated the brand from "Jogja Never Ending Asia" to "Jogja Istimewa".

On this background, the regulation was issued, containing 3 (three) articles, one of them explain about the latest logo of Jogja Istimewa.

As a follow-up to the launch of the new logo "Jogja Istimewa", DIY also made a Strategic Implementation Road Map of the city brand for the Special Region of Yogyakarta.

In general, the roadmap contains: (1) the goals and objectives of "Jogja Gumbregah" (spirit of awakening Jogja) as a follow up City Branding DIY; And (2) strategy, policy direction, and indicative action plan to implement the goals and objectives of "Jogja Gumbregah" as the follow-up of DIY City Branding.

\section{B. City Branding Institutions}

The Law Number 13 of 2012 on the Special Region of Yogyakarta, has affirmed the privilege of DIY itself. In the spirit of Jogja Renaissance, Jogja brand needs to be refreshed, since the state of Indonesia and Jogja has changed. To respond to the changes and confirm the spirit of Jogja renaissance, in 2014 the local government re-brand Jogja. A series of research to explore the spirit of the Jogja Renaissance from the stakeholders, identify the key elements, and translate the rebranding philosophy into the brand visual identity.

With regards to Jogja's ongoing rebranding process, the Jogja's rebranding workflow need to be mapped. Currently, the program and activities of DIY city branding are attached to the programs and activities of the Regional Secretary's Privilege Assistant Unit. The Head of the Assistant Unit is assisting the Regional Secretary to put the Governor's direction to an implementation plan, then to supervise, coordinate, monitor and evaluate the City's privilege matters. Implementation of the DIY city branding program and activities falls under the Regional Planning and Development Agency.

The Regional Government also established an implementation monitoring agency "Jogja Istimewa" consisting of Steering Committee and Implementing Team with the number of members according to expertise in the Jogja Renaissance concept, which is 1. Education, 2. Tourism, 3. Technology, 4. Economics, 5. Energy, 6. Food, 7. Health, 8. Citizen Protection, 9. Spatial Plan and Environment

The Monitoring team is nicknamed Team 11, formed from non-government personnel.

Based on the information from Dagadu Djogja Owner, this team is a combination of several parties. The following figures play a role in determining the new logo of Jogja: Herry Zudianto, Community Leader, Chairman of PMI DIY (Coordinator), Butet Kertarajasa, Artist, cultural expert, Sumbo Tinarbuko, Lecturer DKV FSR ISI Yogyakarta, activist Jogja Emergency Logo, Ong Hari Wahyu, Artist, Senior Graphic Designer, Ahmad Noor Arief, President Director Dagadu Djokdja, Marzuki Mohamad, Artist, Founder Jogja Hiphop Foundation, dr. Tandean Arif Wibowo, IMA Yogyakarta, Waizly Darwin, CEO Marketeers, Markplus, M. Suyanto, Amikom Yogyakarta, Fitriani Kuroda, Jogja International Heritage Walk, M. Arief Budiman, P3I Pengda DIY.

Their task is (1) translating the philosophical concept of Jogja Istimewa to strategic instruction, in the form of strategic concept and Road Map of Strategic Implementation Plan (2015 achievement indicator) that direct the units under the authority the Governor. (2) Provide opinions to the Governor, whether requested or not (3) Supervise the implementation of privilege programs at both the provincial and city / district levels (4) Accommodate and convey the public's aspirations directly to the Governor through an integrated communication and information system (5) Become the drive of the community for the actual implementation of Jogja privilege.

To introduce the new logo and tagline of Jogja, the Local Government of DIY together with Team 11 conducted the 'Pisowanan Agung' in the framework of Jogja Gumregah and 26th Jumenengan (anniversary of the king coronation) of Sri Sultan HB X which was held on Saturday 7 March 2015 at the Kraton Ngayogyakarta Hadiningrat Palace. Pisowanan Agung is an event where the people to pay tribute to the Sultan to in the form of "Jogja Branding" which will become Yogyakarta "treasure" to face the challenges of time. A celebration of public participation in Jogja Rebranding activities as a symbol of the care and love of its citizens. Pisowanan Agung is also shown that the government encourages open discussion and citizen participation for better Jogja.

The Head of Culture Division, of the Assistant of Privileges Unit, stated that the participation of Yogyakarta citizens in " Jogja Rebranding " resulted in the branding of "Jogja Istimewa" along with the values and determination contained therein as a spirit for the better development of Yogyakarta. The motto of Jogja Gumregah is a manifestation of the values and determination of ' Renaissance 9' which underlies the spirit of Jogja Rebranding. Pisowanan Agung was preceded by a pre -event activity on Friday with free T-shirt printing done at Point Zero 
Table 2.

Economic Growth (\%) Regency/City/DIY Year 2010 -2013

\begin{tabular}{ccccc} 
Regency/City/DIY & $\mathbf{2 0 1 0}$ & $\mathbf{2 0 1 1}$ & $\mathbf{2 0 1 1}$ & 2013* \\
Kulon Progo & 3.06 & 4.95 & 5.01 & n.a \\
\hline Bantul & 4.97 & 5.27 & 5.34 & n.a \\
\hline Gunung Kidul & 4.15 & 4.33 & 4.84 & n.a \\
\hline Sleman & 4.49 & 5.19 & 5.45 & n.a \\
\hline Kota Yogyakarta & 4.98 & 5.64 & 5.76 & 5.40 \\
\hline DIY & 4.88 & 5.17 & 5.32 &
\end{tabular}

Source: Province BPS

area of Jogja, from $10.00-17.00$ WIB and Branding of Pedicabs and Andongs (horse-drawn cart) was conducted at Vredeburg Fort parking lot from 14.00 - 17.00 WIB. Pisowanan Agung begins with a cultural parade of 61 contingents from Yogyakarta City, Sleman Regency, Bantul Regency, Kulonprogo Regency, Gunung Kidul Regency, University, the art community, and community. Total parade participants are 2,867 people with 360 volunteers.

The purpose of the launch is to show the spirit of the Jogja governance according to its vision and mission and create exclusive image of Jogja that has been reformulated from "Jogja Never Ending Asia" brand to "Jogja Istimewa" brand.

\section{Inhibiting Factors of City Branding Implementation}

Although City Branding in Yogyakarta has been formed, in the implementation is also not free from obstacles, as written in Roadmap City Branding DIY, 2014

The general reviews are as follows:

First, the programs/activities are still fragmented and do not look to have an integrated grand design, one program and other programs are not supporting each other to present the whole concept.

Secondly, most of the data as the source of the concepts, programs/activities and accompanying budgets are poorly supported with comprehensive information, including a description of the final objective.

Thirdly, the planners and implementers of the programs/activities seem to carry out their duties and responsibilities as just doing business as usual, not vision driven, transforming opportunity to better serve the public and create a better Jogja. Four, the bureaucracy tends to be unconcerned, not responsive and lack of responsibility in responding to problems and public needs.

In the past three years, there has been no program and evaluation activity of the new DIY rebranding result. The implementation of City Branding "Jogja Istimewa" must be evaluated. The objective of the evaluation is to ensure that the improvement of service can be done continuously toward the real "Jogja Istimewa" where it is reflected in every movement, facade and the behavior of the community.

Starting with understanding the meaning of the word "Istimewa" in the tag line branding "Jogja", which has no equivalent in English. It becomes our duty to make the word "istimewa" to be an international word phrase, as well as the words "kampung, durian, orang hutan and gotong royong What is meant by" Istimewa "is a very high quality for its effort toward perfection. If the maximum value of a supreme object is 10 then the "istimewa" is between number 9 and 10 .

The Gap, between the expectation of an almost perfect "Jogja Istimewa" and its reality, means a lot of improvements are badly needed. Therefore, it is urgent to have another Jogja Gumregah Council or another name such as "implementation agency" Jogja Istimewa "in charge of branding implementation of" Jogja Istimewa “.

Another problem is related to the implementation of the city branding. There are some obstacles experienced by Team 11 in monitoring the city branding in Yogyakarta. Head of Privileges Assistant Unit stated that in addition to the cessation of some activities, TIM 11 also has not been able to continue its activities because it is hampered by the budgeting program and the follow-up activities. 
Table 3.

Economic Growth Rate DIY Year 2010-2013

\begin{tabular}{|c|c|c|c|c|}
\hline Year/Indicator & 2010 & 2011 & 2012 & 2013 \\
\hline $\begin{array}{c}\text { Economic Growth } \\
\text { Rate (\%) }\end{array}$ & 4.88 & 5.17 & 5.32 & 5.40 \\
\hline Changes (\%) & - & 0.64 & 0.15 & 0.08 \\
\hline
\end{tabular}

Source: BPS-GDRP Regency/City/DIY 2000-2012, BRS DIY Number 11/2013 dan BRS DIY Number 11/2014, analyzed

\section{Strengthening the Regional Competitiveness with City Branding}

Although the programs and City Branding are currently underway (from 2001-2017 to the present) but the DIY branding already shows a significant achievement. Head of Culture of the Privileges Assistant Unit stated at least the City Branding shows a lot of opportunities for the local government to reap additional revenue from tourists. Not only hotels and restaurants are growing, a number of creative industries are also enjoying the additional income from tourism.

High per capita Gross Regional Domestic Product (GRDP) reflects the better economic condition of the community, and low GRDP per capita reflects the under-developed economy of the society. From the data obtained, each region has a good GRDP on the investment and tourism side every year. It's just that the City Branding is still focused on tourism, although it may be used for other sectors.

The second City Branding made several breakthroughs, by establishing the City Branding institutions, symbolic activities, and its location.

In addition to the increase of GRDP in DIY, DIY economic growth rate also shows some growth.

Table 2 shows that in general DIY economy has increased, i.e. in 2011 the rate of economic growth rose by 5.17 , to 5.32 percent in 2012 and then rose again to 5.40 percent in 2013. During the year 20102012, All Regency/cities in DIY experienced an increase in economic growth rate. In DIY for 2012 and 2013, agricultural sector occupies the third rank, below trade sector, hotel and restaurant sector and services sector in contributing to DIY GRDP.

Ever since the City Branding launched, the tourism industry and the creative economy have produced many results. According to the Head of Tourism Information Service Section, DIY Tourism is the main sector for DIY.

Various objects and tourist attraction in Yogyakarta has attracted tourist visits, both foreign tourists and domestic tourists as shown in the annual report (Tourism Office of Special Region of
Yogyakarta, 2015). In 2014 recorded tourist arrivals of 3,346,180 people, 254,213 are from overseas, and $3,092,967$ are domestic tourists.

DIY tourism includes MICE (Meeting, Incentive, Convention and Exhibition), cultural objects, natural objects, special interest objects, and various other tourist facilities such as resorts, hotels, and restaurants.

The diversity of religious ceremonies, and cultures of various religions, supported by artistic creativity, and community hospitality, DIY is able to create promising cultural products and tourism.

Based on some of the reviews above, DIY is attempting to develop place marketing with the target group. DIY economic growth rate indicates that the year 2010 economic growth rate is still at $4.53 \%$ but in 2013 the rate of economic growth DIY has reached $5.40 \%$.

Table 3 explains although the economic growth rate of DIY continues to increase every year, there has been no significant increase in the year to year the growth rate, the year to year increase is actually tends to be less every year. From 2012 to 2013 the economic growth rate only increased $0.08 \%$, whereas from 2010 to 2011 the change in economic growth rate reached 0.64 percent.

The GDRP of the city is an important part in reviewing the success of City Branding, DIY efforts in promoting its brand benefited the investors and increase the arrival of tourists. In DIY, the trade sector of hotels and restaurants still dominate the GRDP. In 2010 GRDP in the trade sector of hotels, and tourism is 9 trillion rupiahs. In 2011 increased to 10 trillion, 11 trillion in 2012, and 13 trillion in the year 2013. Another big contributor of DIY GRDP in the service sector. In 2010 amounted to 9 trillion, in 2011 amounted to 12 trillion, 11 trillion in the year 2012 and in the year 2013 amounted to 12 trillion. Total GRDP if associated with GDP of oil and gas sector is 45 million, in 2011 is 51 trillion, in 2012 is 57 trillion, and in 2013 is 63 trillion (BPS, 2015).

If you look at the data presented above, in tune with the theoretical framework commissioned by 
Prophet (2006), there are several key points in City Branding.

First: Set the objectives of the City Branding and understand the target audience. We see DIY determined that tourism is the objective of its City Branding. City branding in DIY is also related to the city planning, which can be a strategy for a city to create a strong positioning in the target marketing, as the positioning of a product or service would. Marketing is inseparable from competition, even for a city. To gain trust as the best city in a particular aspect, would depend on how the city branding has been created and delivered as a competitive strength and the relevance of the city so that the city can be widely recognized both regionally or global.

Second: Identifying the current brand image and arrange the aspirational identities of the brand. As carried out by the Yogyakarta Provincial Government, the process of rebranding or reimagining of the Special Territory of Yogyakarta is directed to be a cultural movement involving the wider community. Thus, this rebranding not only produces new logos and slogans but also a socialization of new values and spirit to the citizens of Yogyakarta.

Third: developing positioning steps and creating value propositions.

The value of the proposition arises because of the successful positioning steps created. In DIY, the provincial government sees it. This aspect becomes important because it involves the reason why the target audience should visit the DIY. This is why the City Branding is important for DIY since 2001.

Fourth: Implement the steps of branding strategy.

DIY issued Strategic Implementation Road Map Plan of the DIY City Brand. The Roadmap contains: (1) formulation the goals and objectives of "Jogja Gumbregah" (spirit of awakening) as the follow up DIY City Branding; And (2) Formulation of strategy, policy direction, and indicative action plan to realize the goals and objectives of "Jogja Gumbregah" as the follow-up of DIY City Branding.

Fifth: measure the result.

As far as the author knows, there is no document in evaluating this rebranding result. This is reinforced by the Cultural Assistant of the Privilege Assistant Unit. Rebranding Jogja is still in the process of improving the implementation in the community.

But from the above discussion, there are benefits from the creation of City Branding.

First is that the sub-brand will be an established organizational structure within the City (e.g., the separation of tourism and business development).

The concept for the policy making and subbrand management location should be more efficient, leading to new tasks in the management of place branding. This branding process is not limited to the communication aspect, the most important thing is the physical location which should have a real characteristic since they greatly affect the perception of place branding. The management of place branding develops a place to meet the demands of the customer, and to be honest in describing the place (Ashworth \& Voogd, 1990; Morgan et al., 2002; Trueman et al., 2004).

Second is regional competitiveness.

DIY strategy in increasing its competitiveness is by using place marketing and developing it to be a place branding. In other words, the place branding is being used as a strategic effort in communicating the place to improve its economic growth. The effort to communicate a place as a brand is still needed, especially for an area that has the potential to be developed as a potential tourism area, which includes natural objects, a historical city, cultural events and sports that encourage the growth of migrants, Investment, and more. The success of the strategy of establishing a place as a brand depends on the stakeholders involved, either the government, private sectors, and community, working together in developing policy and procedures to develop attractive destination branding that involves not only the natural aspect and infrastructure development.

\section{Conclusion}

First, City Branding DIY has been running well. DIY Rebranding is likely to increase the competitiveness of the region, including local revenue, as shown by the increase in investment achieved by the Government of DIY. The downside is that the City Branding is still focused on tourism although it can be used for other sectors.

Second, the DIY rebranding (2014) showed many improvements, especially in terms of concept, logo, and tagline. In addition, the DIY government has established city branding councils, city branding strategy roadmap and issued governor regulation of city branding. However, there has been no evaluation since the rebranding was done by the provincial government of DIY on how this rebranding can be implemented by the local government and city branding council and the extent to which the strategy in the roadmap is being implemented.

Our recommendation is that the Government of DIY may create programs and indicative activities that can be the quick wins of the implementation of Jogja Istimewa, as follows:

First, it is necessary to harmonize the City Branding regulations and programs, from the central, provincial and regency/city government.

The identity needs to be exotic, that combining romanticism of future sophistication. City Branding as a product of local government policy should be 
included in the corridor of regional innovation as regulated in Law Number 23 of 2014, then in this context, Regional City Branding may be expected to articulate the uniqueness of its region in the form of regional innovation, so that City Branding has become unity in an innovative policy can (? unfinished sentence)

Second: We are appealing to the Local Government to form City Branding in Triple Helix elements, Intellectual, Business, and Government.

On the government structure, should involve various SKPD consisting of SKPD in the field of economy and R\&D. Stakeholders need to be expanded: SKPD, creative teams, private sectors, community members/NGOs, village government, User of IT for City Branding, including IT managers. In addition, local governments can open centralized communication channels to accommodate all input, suggestions, and critiques from the public through the Hotline (telephone, short message, email, etc.) and social media (website, Twitter, Facebook, Instagram, YouTube, etc.) as well as the followup of the inputs in one system which is integrated with all SKPD, and which progress of complaint handling is open to the public and can be widely accessed. Making a Jogja Istimewa Brand Book with have a comprehensive and complete as a guide to the implementation of logos \& tagline for internal government institutions from provincial level to city/Regency to ensure that public communication would use a common language.

\section{ACKNOWLEDGEMENT}

We would like to thank the Head of the Research and Development Agency, Head of the Center for Innovation Research and Development of the Ministry of Home Affairs' Research and Development Agency, Yogyakarta Special Region Governor, Researcher of Balitbang Dr. Herie Saksono and Sociologist Ivanovic Agusta (IPB) who has provided much input for this article.

\section{REFERENCES}

Adiningsih, S. et al. (2008). Satu Dekade Pasca-Krisis Indonesia: Badai Pasti Berlalu? Yogyakarta: Kanisius.

Akgun, A. E., Zehir, C., Ayar, H., \& Keskin, H. (2016). Tales of Cities: City Branding Through Storytelling. Journal of Global Strategic Management, 1(10), 31-31. http://doi. org/10.20460/JGSM.20161022384

Berg, B. L. (2001). Qualitative Research Methods For The Social Sciences. (Sarah L. Kelbaugh, Ed.) (4th ed.). United State of Amerika: California State University.

Caldwell, N., \& Freire, J. R. (2004). The Differences Between Branding a Country, A Region and A
City: Applying the Brand Box Model. Journal of Brand Management, 12(1), 50-61. http://doi. org/10.1057/palgrave.bm.2540201

Christin, Maylanny; Fauzan, S. F. (2013). City Branding Kota Bandung melalui Bus Bandros. Jurnal Ilmu Komunikasi Universitas Telkom, (1).

Daerah, B. perencanaan pembangunan. (2014). Road Map Perencanaan Strategis Implementasi City Brand Daerah Istimewa Yogyakarta. Yogyakarta: Bappeda DIY.

Denzin, N. K. (2012). Triangulation 2.0. Journal of Mixed Methods Research, 6(2011), 80-88.

Dimasyq Ozal. (2012). Indonesia Bisa Bertahan dari Krisis Global - Kompas.com. Retrieved April 19, 2017, from http://bisniskeuangan. kompas.com/read/2012/07/08/13274536/ Indonesia.Bisa.Bertahan.dari.Krisis.Global

Dinas Pariwisata Daerah Istimewa Yogyakarta. (2015). Statistik Kepariwisataan 2014. Yogyakarta.

DIY, P. (2011). Jogja Never Ending Asia.

Kavaratzis, M., \& Ashworth, G. J. (2005). City Branding : an Effective Assertion of Identity or a Transitory Marketing Trick ?, 96(5), 506-514.

Klaus Schwab, W. E. F. (2016). The Global Competitiveness Report 2016-2017. World Economic Forum Reports 2016. Geneva. http://doi.org/92-95044-35-5

Lea. (2016). Yogyakarta Menjadi Kota Terbaik Kategori Pariwisata - Berita Daerah. Retrieved April 19, 2017, from http://beritadaerah. co.id/2016/09/29/yogyakarta-menjadi-kotaterbaik-kategori-pariwisata/

Medic, M., Banozic, M., \& Pancic, M. (2010). Branding Impact on the Economic Development of Cities and Counties - Example Branding City of Ilok. Interdisciplinary Management Research Vi, VI, 152-161.

OECD. (2015). Survei Ekonomi OECD INDONESIA. Jakarta. Retrieved from https://www.oecd. org/economy/Overview-Indonesia-2015Bahasa.pdf

Pemerintah Republik Indonesia. (2014). UndangUndang Republik Indonesia Nomor 23 Tahun 2014 tentang Pemerintahan Daerah. Jakarta: Sekretariat Negara.

Pessoa, A. (2013). Competitiveness, clusters and policy at the regional level: Rhetoric vs. Practice in designing policy for depressed regions. Regional Science Inquiry, 5(1), 101-116.

Prophet. (2006). Branding Your City. CEOs For Cities. Chicago: Prophet.

Purwanti, Lily; Lukito, Y. R. D. L. (2014). Analisis Pengaruh City Branding Kota Batam Terhadap Brand Attitude (Studi kasus pada stakeholder di Kota Batam). Jurnal Manajemen, 14(1), 6180 . 
Risanto, Y., \& Yulianti, I. (2016). City Branding Strategy on the Evaluation of Tourism Destination Problems in Rural Area (Evidence from Pasuruan City, Indonesia). Journal of Indonesian Tourism and Development Studies, 4(1), 5-12. Retrieved from http://www.jitode. ub.ac.id/index.php/jitode/article/view/168
Somantri, G. R. (2005). Memahami metode kualitatif. Makara, Sosial Humaniora, 9(2), 57-65. Retrieved from http://journal.ui.ac.id/index. php/humanities/article/view/122/118

Wibowo, A., \& Poesoro, L. (2005). Membangkitkan investasi di Indonesia. 